\title{
Напрями розвитку вітчизняних самохідних артилерійських систем на основі аналізу зразків артилерійського озброєння провідних країн світу
}

\author{
Андрій Кісліцин * 1 А; Микола Дорофєєв 2 А \\ А Науково-дослідний центр ракетних військ і артилерії, м. Суми, Україна \\ в Центральний науково-дослідний інститут озброєння та військової техніки Збройних Сил України, м. Київ, Україна
}

Received: November 15, 2021 | Revised: December 10, 2021 | Accepted: December 30, 2021

DOI: $10.33445 /$ sds.2021.11.6.7

\begin{abstract}
Анотація
Збройна агресія Російської Федерації на сході України внесла суттєві корективи в вітчизняний розвиток озброєння та військової техніки як у нашій країни так і за кордоном. Розвиток артилерійського озброєння, як основного виду вогневого ураження противника за досвідом антитерористичної операції (операції Об'єднаних Сил), є пріоритетним, оскільки чималий відсоток завдань з вогневого ураження противника припадає саме на артилерію. В даній статті розглянуто питання щодо формування напрямків розвитку вітчизняних самохідних артилерійських систем на основі аналізу зразків артилерійського озброєння провідних у військовому відношенні країн світу. Слід зазначити, що широке впровадження сучасних технологій та науково-технічних рішень для підвищення ефективності застосування зразка озброєння та військової техніки є одним з головних напрямів розвитку артилерійського озброєння для часткового вирішення проблем, пов'язаних з розвитком форм збройної боротьби.
\end{abstract}

Ключові слова: САУ, інерційні системи навігації та наведення, НАТО, аналіз, снаряд.

\section{Постановка проблеми}

Аналіз застосування артилерійських підрозділів у вогневому ураженні противника свідчить про те, що артилерії надається провідна роль у вогневому ураженні противника [1]. Разом з тим, аналіз бойового застосування артилерійських підрозділів у ООС (АТО) показав й низку недоліків. Насамперед, це тривалий час на підготовку підрозділів артилерії до виконання вогневого завдання на вогневій позиції, технічний стан артилерійського озброєння (значна як технічна так і моральна застарілість зразків ОВТ). Розроблення нових та модернізація існуючих артилерійських систем $€$ нагальною потребою сьогодення. Значна кількість зразків самохідних артилерійських установок (САУ) у артилерійських підрозділах Збройних Сил України виготовлена ще за часів Радянського союзу та, в основному, вичерпала граничний строк експлуатації. Отже, ведення сучасних бойових дій вимагає відповідного технічного стану ОВТ, яке, в свою чергу, на даний час вже не відповідає сьогоденню. Крім того, враховуючи курс країни на співробітництво 3 країнами НАТО, виникає необхідність переходу на єдиний стандарт зразків ОВТ, зокрема, на 155-мм калібр ствольної польової артилерії.

\section{Аналіз останніх досліджень та публікацій}

Питанням розвитку та модернізації артилерійських систем приділяють увагу збройні сили провідних країн світута військове керівництво Збройних Сил України. В

\footnotetext{
1 * Corresponding author: Науковий співробітник науково-дослідного відділу, e-mail: kislitsyn.andrey14@gmail.com, ORCID: 0000-0001-9838-7896

2 Науковий співробітник науково-дослідного відділу, e-mail: dorofeev83@meta.ua, ORCID: 0000-0001-8607-2483
} 
наведених ресурсах і публікаціях [2, 3] модернізації, так і заміну систем, бойові розглядаються окремі питання щодо характеристики яких вже не відповідають розроблення артилерійських систем. сучасним вимогам. Існує доцільність

Аналіз стану самохідної артилерії в проведення переходу з калібру 152-мм на підрозділах артилерії Сухопутних військ калібр 155-мм зі стволами, що відповідають Збройних Сил України вказує, що всі наявні єдиному стандарту НАТО [1]. самохідні артилерійські системи потребують як Постановка завдання

Метою статті $\epsilon$ визначення напрямів розроблення вітчизняних самохідних артилерійських систем на основі аналізу

відомих зразків самохідних артилерійських систем провідних країн світу.

\section{Виклад основного матеріалу}

На сьогоднішній день на озброєнні ЗС України знаходяться такі САУ 152-мм калібру як 2С3М “Акація”, 2С5 “Гіацинт-С”, 2С19 “Мста-С”(табл. 1).

Таблиця 1 - Основні ТТХ самохідних артилерійських установок 2С3, 2C19, 2 С5

\begin{tabular}{|l|c|c|c|}
\hline \multicolumn{1}{|c|}{ Основні ТTX } & $\mathbf{2 C 3}$ & $\mathbf{2 C 1 9}$ & $\mathbf{2 C 5}$ \\
\hline Рік прийняття на озброєння & 1971 & 1989 & 1976 \\
\hline Бойова маса, Т & 27,5 & 42 & 27,5 \\
\hline Екіпаж/обслуга, чол. & $6 / 4$ & $5 / 7$ & 5 \\
\hline Швидкість руху, км/год: & & & 25 \\
по грунту & 45 & $35-45$ & 60 \\
по шосе & 63 & 60 & СУ-100п \\
\hline База & СУ-100п & спец.(Т-72) & 152 \\
\hline Калібр, мм & 152 & 152 & 60 \\
\hline Боєкомплект., пострілів, шт: & & & 30 \\
всього & 60 & 60 & \\
возимий & 46 & 50 (20 ОФС, 30 АРС) & 28400 \\
\hline Дальність стрільби, М: & & & 33000 \\
ОФС & 17300 & 24700 & 6 \\
АРС & 20300 & 28900 & $7-8$ \\
\hline Скорострільність, постр./хв. & 3 & & \\
\hline
\end{tabular}

У той же час, досвід проведення антитерористичної операції, а згодом операції Об'єднаних сил на сході України, свідчить, що 152 мм САУ, які знаходяться на озброєнні Сухопутних військ Збройних Сил України, вже не повною мірою забезпечують ефективне виконання широкого спектру завдань, які покладаються на артилерію в сучасному бою [2].

Для визначення напрямів розвитку вітчизняних самохідних артилерійських систем проведемо порівняльний аналіз кращих аналогів САУ провідних країн світу.

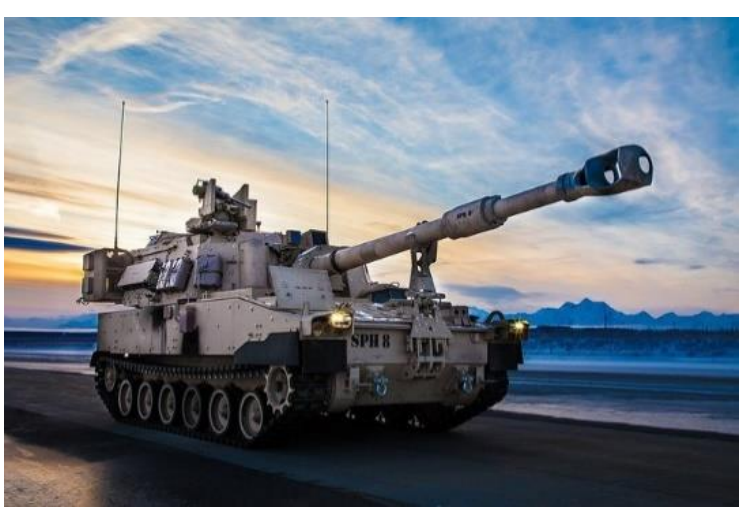

Рисунок 1 - Самохідна гаубиця (СГ) модифікації М109А6, М109А7 (США)

Основні тактико-технічні характеристики 155 мм СГ М109A6, М109A7 наведено у табл. 2. 
Модифікація СГ М109А6 "Паладин" (Paladin), яка є на озброєнні Сухопутних військ США, була введена в експлуатацію в 1993 році [4].

В ході робіт з модернізації бортової системи управління СГ “М109A6" на неї було встановлено:

- цифрових бортовий балістичний обчислювач;

- засоби закритого цифрового зв'язку 3 автоматичною зміною частоти;

- вдосконалена інерціальна система навігації, наведення та локалізації;

- бортова радіолокаційна станція вимірювання початкової швидкості снаряда;

- система діагностики;

- прилад нічного бачення для механікаводія.

Завдяки проведеним роботам 3 модернізації СГ М109A6 артилерійський вогневий взвод здатний виконувати бойові завдання автономно, що відображено в бойовому статуті Сухопутних військ США, розробленому спеціально для підрозділів, що мають на озброєнні ці САУ. Отримавши під час маршу бойове завдання, екіпажі розраховують дані для стрільби, не залишаючи бойового відділення, переводять САУ 3 похідного положення в бойове, готують вогневу позицію. Зазвичай розрахунок даних здійснюється спільно з центром управління вогневим взводом, який розміщений на командноштабній машині. В екстрених випадках екіпаж готує дані самостійно. Час підготовки першого пострілу становить 60 с. Після зупинки екіпаж гаубиці готовий до стрільби через 30 с. Для здійснення трьох пострілів їй необхідно 20 с. Можливо, що вже після першого пострілу САУ змінить вогневу позицію з метою підвищення живучості за рахунок виключення ураження в контрбатарейній боротьбі.

Модифікація СГ М109A6 PIM була введена в експлуатацію у 2017 році, потім назва СГ САУ була змінена на М109A7 [4].

Найбільш суттєвими змінами М109A7 є:

- використання шасі бойової машини піхоти "Bradley" з метою уніфікації базового шасі;
- оснащення САУ двигуном потужністю 600 к./с. і автоматичною трансмісією, що підвищило питому потужність на 10-14\%;

- вдосконалення

електросистеми, включаючи установку генератора потужністю 70 кВт з вихідною напругою 600 В для живлення приводів башти та іншого обладнання;

- ємність паливних баків збільшена на 10\% для збереження запасу ходу по паливу до 300 $\mathrm{KM}$;

- траки шириною 356-мм замінено двосекційними ХТ-161 шириною 485-мм (на 36\% зменшення тиску на ґрунт);

- подовження корпусу машини дозволило довести боєкомплект, що перевозиться, до 42 снарядів, включаючи 10-15 шт. М982 (високоточний снаряд 3 круговим ймовірнісним відхиленням до 10м. Сучасні зразки артилерійського озброєння застосовують боєприпаси, які застосовують дані супутникової навігації для отримання високої точності влучання);

- у башті гаубиці встановлено напівавтоматичний досилач зарядів та електричні приводи (збільшення скорострільності на $20 \%$ та зменшення навантаження на розрахунок гармати під час інтенсивної стрільби);

- картузні метальні заряди замінено модульними.

Скорострільність варіанта СГ М109А7 складе 4 постр./хв протягом перших 3 хв. Режим MRSI (Multiple Rounds Simultaneous Impact одночасний удар кількох снарядів по цілі при зміні кута підвищення однією гарматою) для гаубиці не передбачено через небезпеку перегріву ствола.

Система управління вогнем СГ М109A7 (СУВ) забезпечує автоматизацію процесу підготовки стрільби і ведення вогню керованими снарядами, в тому числі, з використанням даних цілевказівки АСУ наземною артилерією AFATDS (Advanced Field Artillery Tactical Data System - удосконалена тактична цифрова система польової артилерії). Ї̈̈ функціонування підтримується системою обробки та аналізу 
інформації, що надходить від пілотованих засобів повітряної радіолокаційної, радіо-, радіотехнічної розвідки і безпілотних літальних

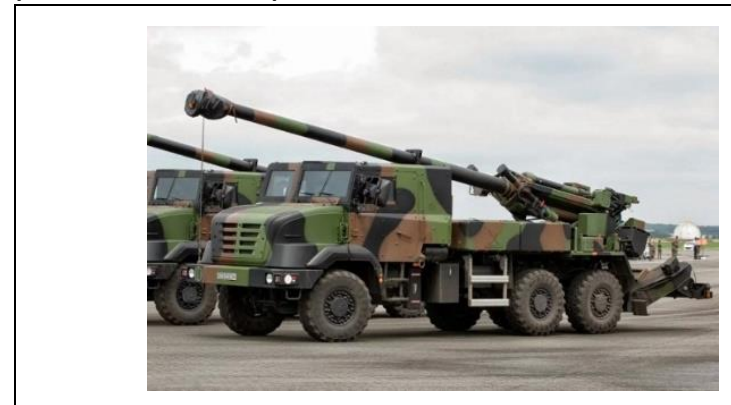

апаратів, що в свою чергу, значно підвищує ефективність застосування зразка.

Рисунок 2 - 155 мм самохідна артилерійська установка “Caesar" (Франція)

Основні тактико-технічні характеристики САУ наведено у табл. 2.

До складу комплексу САУ входить вся необхідна апаратура для самостійних дій і швидкого розгортання в бойових умовах. САУ оснащена інерціальною навігаційною системою "Sigma 30" компанії "Sagem", балістичною радіолокаційною станцією RDB4, балістичним обчислювачем CS2002, приймачем супутникової навігаційної системи, сучасними засобами радіозв'язку [5].

Балістична радіолокаційна станція RDB4, встановлена праворуч від ствола, вимірює початкову швидкість снаряда та передає на бортовий комп'ютер CS 2002 системи управління вогнем, який знаходиться у кабіні. Це дозволяє проводити розрахунок поправок під час кожного пострілу індивідуально.

Наведення гармати виконується за допомогою системи управління вогнем в автоматичному режимі, також може здійснюватися вручну за допомогою оптичних приладів. Переведення САУ 3 похідного положення в бойове виконується менш ніж за 1 хв. За твердженням виробника, потрібно не більше 2 хв на здійснення черги 3 шести пострілів, повернення в похідне положення і початок висування на нову вогневу позицію.

Оснащення САУ інерціальною навігаційною системою та топоприв'язки дозволяє визначати установки для стрільби кожній гармати та здійснювати автономне орієнтування гармати. У свою чергу це дозволить здійснювати розосереджене розміщення гармат на вогневій позиції. Крім того, висока точність топогеодезичної прив'язки дозволить застосовувати снаряди з коригуванням траєкторії руху за допомогою систем супутникової навігації.

Головний блок (рис. 3) інерціальної навігаційної системи розташовується з правої (вгорі) сторони гармати (з боку помічника навідника), якщо дивитися на гармату з його казенної частини [5].

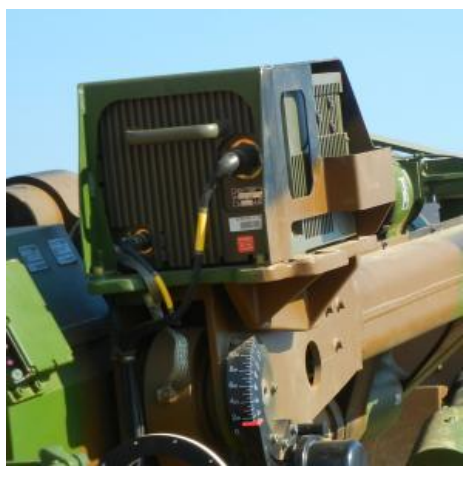

Рисунок 3 - Інерціальна навігаційна система "Sigma 30". 
Оснащення САУ передбачає автоматичну система подачі снарядів. Максимальна скорострільність САУ становить 6 пострілів за хвилину. При цьому в режимі MRSI гармата здійснює 4 постріли за 20 секунд. Приводи системи наведення гармати - гідравлічні (основний) і ручні (допоміжний). Кут горизонтального наведення гармати при кутах вертикального наведення від $17^{\circ}$ до $66^{\circ}$ становить $34^{\circ}$. А при веденні вогню прямою наводкою (кути вертикального наведення від $3^{\circ}$ до $\left.+10^{\circ}\right)-48^{\circ}$.

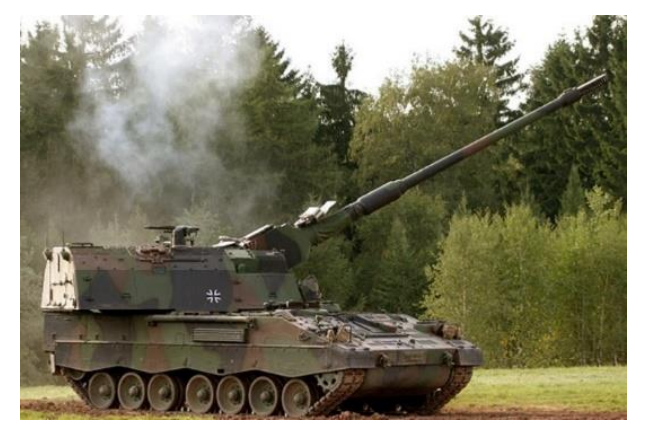

Рисунок 4 - 155-мм самохідної гаубиці “РzH 2000” (ФРН)

Основні тактико-технічні характеристики САУ наведено у табл. 2.

“PzH 2000" - 155 мм гаубиця з довжиною ствола 52 калібри, яка встановлена у башті кругового обертання. Діапазон кутів вертикального наведення складає від $-2,5^{\circ}$ до + $65^{\circ}$. Канал ствола хромований, що продовжує термін його експлуатації на 20-25\%. Об'єм зарядної камори становить 23 л відповідно "Спільного меморандуму про балістику" країн НАТО. Гармата має щілинне дульне гальмо нового зразка, яке зменшує інтенсивність спалаху при покиданні снарядом ствола гармати та збільшує початкову швидкість снаряда приблизно на $15 \%$ у порівнянні 3 класичним дульним гальмом. Напівавтоматичний клиновий затвор оснащений магазином на 32 стандартних капсулидетонатори з кільцевим конвеєром [7].

Максимальна дальність ведення вогню стандартним снарядом L15A2 становить 30 км, снарядом з донною насадкою- близько 35 км, активно-реактивними боєприпасами - 40 км. Разом з тим, гаубиця може вести вогонь і $з$ застосуванням традиційних зарядів “натовського” стандарту.

САУ може вести вогонь й іншими типами снарядів - наприклад, касетними DM642, які споряджені 63 осколковими бойовими елементами (дальність стрільби - 27,1 км). У боєкомплект САУ входить і снаряд SMArt 155 мм (DM702A1), що містить два самонавідних суббоєприпаси (система наведення останніх включає інфрачервоні датчики та мікрохвильовий радар). Важить такий снаряд 47 кг, дальність стрільби - 27,5 км.

У 2006 році САУ провела випробувальні стрільби активно-реактивним снарядом V-LAP, розробленим південноафриканською фірмою "Denel", на дальність 56 км. Цей показник не $€$ граничним - він був обмежений розмірами полігону. У кінці 2013 року відбулися випробувальні стрільби американським керованим снарядом M982 "Excalibur". Мінімальна дальність стрільби цим боєприпасом становить 9 км, максимальна - 48 км.

САУ обладнана двома прицілами панорамним PERI R19 і TN80 (8-кратного збільшення), що служить для ведення вогню прямим наведенням. $€$ і лазерний далекомір 3 діапазоном вимірювання дальності до 2800 м. Командир САУ має перископічний прилад спостереження PERI-RTNL80 зі змінним збільшенням (2- і 8-кратним). Крім того, до бортового оснащення “PzH 2000” входить радар для виміру початкової швидкості кожного випущеного снаряда для врахування поправок при стрільбі. Його фазована антенна решітка встановлена на передній частині башти [7]. 


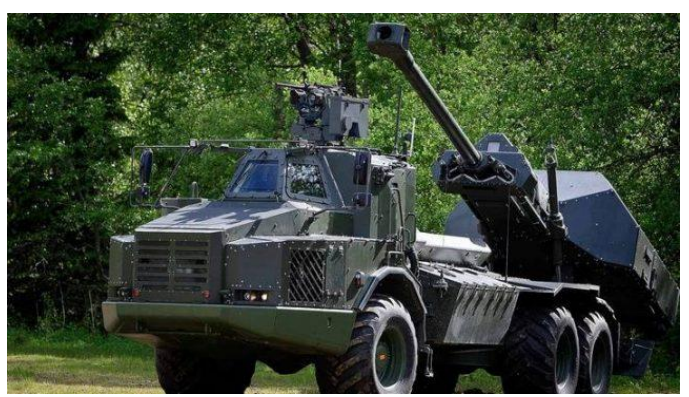

Рисунок 5 - 155-мм CAУ FH77BW L52“Archer” (Швеція)

Основні тактико-технічні характеристики САУ наведено у табл. 2.

CAУ використовує шасі автомобіля Volvo A30D 3 колісною формулою $6 \times 6$. На шасі встановлено дизельний двигун потужністю 340 к. с., який дозволяє розвивати швидкість на шосе до 70 км/год.

При розробленні САУ враховувалася необхідність зменшення часу на підготовку до стрільби і залишення вогневої позиції. В результаті частина підготовки до ведення вогню САУ може здійснювати ще на шляху до позиції. Завдяки цьому перший постріл робиться вже через 30 секунд після зупинки в потрібній точці маршруту. За цей час опускаються аутригери і приводиться в бойове положення башта. Після виконання вогневої задачі екіпаж переводить бойову машину в похідне положення і залишає вогневу позицію. На підготовку до відходу з позиції так само йде близько 30 секунд [8].

Під час бойової роботи екіпаж САУ постійно знаходиться на своїх робочих місцях і не залишає їх. Всі операції здійснюються за командами з пультів управління. У зв'язку $з$ цим, всі механізми башти працюють в автоматичному режимі.

Основними елементами оснащення башти $\epsilon$ механізми заряджання. За наявними даними, замість єдиної системи САУ використовує два взаємодіючих один з одним механізми. Ємність механізованого укладання подає 155мм снаряди, система заряджання оперує зарядами, що поставляються у вигляді циліндричних блоків з оболонкою, яка згорає, та подібний до зарядного картузу. Об'єм боєукладки дозволяє розмістити у боєукладці башти САУ 126 блоків з метальним зарядом. Механізми заряджання гармати забезпечують скорострільність до 8-9 пострілів за хвилину, при веденні вогню у режимі MRSI - 4-6 пострілів за хвилину залежно від дальності стрільби. САУ також може використовувати керовані снаряди "Excalibur" або йому подібні за типом, а автоматика буде виконувати підготовку боєприпасу до стрільби.

САУ оснащується сучасною цифровою системою управління вогнем. Електронне обладнання та пов'язані 3 ним системи дозволяють екіпажу здійснювати всі необхідні операції, не залишаючи робочі місця.

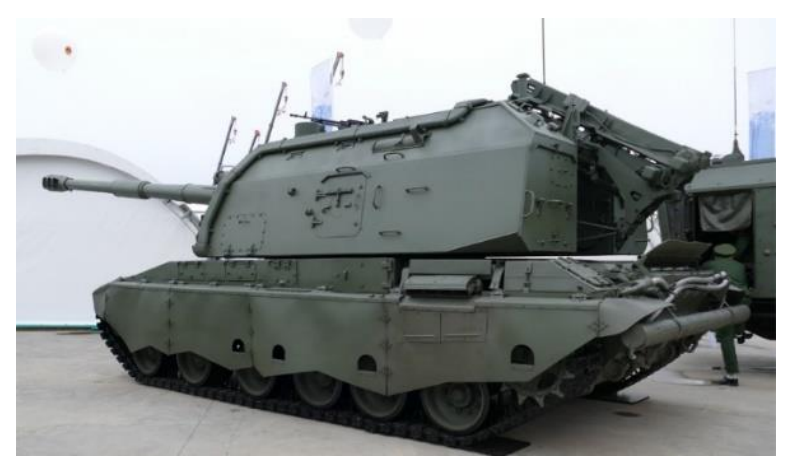

152 мм самохідної гаубиці 2С19М2 (РФ) 
Основу вогневої потужності САУ становить гармата 2А64M2 калібру 152-мм зі скорострільністю 10 пострілів за хвилину.

Таких показників вдалося досягти завдяки модернізації конструкції механізмів заряджання. Автоматизація процесу заряджання при будь-яких кутах підвищення, автоматичний вибір типу снаряда, автоматичний викид стріляних гільз забезпечує зниження фізичних навантажень екіпажу і підвищує скорострільність.

Стелажі боєприпасів усередині башти мають конструкцію, яка дозволяє розташувати всі штатні типи снарядів, причому, вибір потрібного з них, а також управління всім процесом заряджання здійснюється за допомогою контрольної системи механізму заряджання.

САУ здатна виконувати противогневий маневр з автономним визначенням поточних координат. Забезпечується режим “одночасний вогневий наліт", при якому ціль уражається одночасно декількома снарядами, випущеними з однієї гармати.

Для захисту від високоточної зброї використовується комплект “Накидка", який знижує помітність САУ в радіолокаційному та тепловому діапазонах.

Додатково САУ оснащена автоматичною протипожежною системою триразової дії 3 апаратурою управління ЗЕЦ11-2, двома фільтровентиляційними установками, системою самообкопування, термодимовою апаратурою, системою 902У “Туча" для стрільби 81-мм димовими гранатами, двома танковими дегазаційними приладами. Крім того, на САУ $€$ комплект обладнання для підводного водіння, що дозволяє машині долати водні перешкоди глибиною до п'яти метрів.

Таблиця 2 - Основні тактико-технічні характеристики вищезазначених САУ

\begin{tabular}{|c|c|c|c|c|c|c|c|}
\hline Характеристики & СГ M109A6 & СГ M109A7 & $\begin{array}{c}\text { CAY } \\
\text { "Caesar" }\end{array}$ & $\begin{array}{c}\text { CAY } \\
\text { "Caesar" }\end{array}$ & CAY “PzH 2000” & $\begin{array}{c}\text { CAY } \\
\text { "Archer" }\end{array}$ & Сг 2C19M2 \\
\hline Екіпаж, осіб & 4 & 4 & $3-5$ & 3-5 & 5 & 3 & 5 \\
\hline Колісна формула & & & $6 \times 6$ & $8 \times 8$ & & & \\
\hline Шасі вантажівки & $\begin{array}{c}\text { шасі } \\
\text { бойової } \\
\text { машини } \\
\text { піхоти } \\
\text { "Bradley" }\end{array}$ & $\begin{array}{c}\text { шасі } \\
\text { бойової } \\
\text { машини } \\
\text { піхоти } \\
\text { “Bradley" }\end{array}$ & $\begin{array}{c}\text { “Sherpa" } \\
\text { Renault } \\
\text { Trucks } \\
\text { Defense }\end{array}$ & Tatra T815 & $\begin{array}{c}\text { Вузли та } \\
\text { агрегати танку } \\
\text { "Leopard-2" }\end{array}$ & $\begin{array}{l}\text { "Volvo" } \\
\text { A30D }\end{array}$ & $\begin{array}{c}\text { Вузли та } \\
\text { агрегати } \\
\text { Т-80 }\end{array}$ \\
\hline Бойова маса, т & 34,25 & до 39,00 & 17,70 & 32 & 57,66 & 33 & 43,2 \\
\hline $\begin{array}{c}\text { Боєкомплект, } \\
\text { кількість } \\
\text { снарядів }\end{array}$ & 39 & 42 & 18 & 30 & 60 & 21 & 50 \\
\hline $\begin{array}{c}\text { Довжина ствола, } \\
\text { клб }\end{array}$ & 39 & 39 & 52 & 52 & 52 & 52 & 47 \\
\hline $\begin{array}{c}\text { Максимальна } \\
\text { дальність } \\
\text { стрільби, км ОФ }\end{array}$ & 22 & 22 & 30 & 30 & 30 & 30 & 24,7 \\
\hline $\begin{array}{c}\text { Максимальна } \\
\text { дальність } \\
\text { стрільби, км АРC } \\
\end{array}$ & 30 & 30 & 42 & 42 & 40 & 40 & 29 \\
\hline $\begin{array}{c}\text { Максимальна } \\
\text { дальність } \\
\text { стрільби, км } \\
\text { Excalibur Block } \\
\text { 1а-2 (снаряд зі } \\
\text { збільшеною } \\
\text { дальністю) }\end{array}$ & $40-60$ & $40-60$ & & & 48 & 50 & \\
\hline
\end{tabular}




\begin{tabular}{|c|c|c|c|c|c|c|c|}
\hline Характеристики & СГ M109A6 & СГ M109A7 & $\begin{array}{c}\text { CAY } \\
\text { "Caesar" }\end{array}$ & $\begin{array}{c}\text { САУ } \\
\text { "Caesar" }\end{array}$ & CAY “PzH 2000" & $\begin{array}{c}\text { CAУ } \\
\text { "Archer" }\end{array}$ & СГ 2C19M2 \\
\hline $\begin{array}{c}\text { Максимальна } \\
\text { дальність } \\
\text { стрільби, км АРC } \\
\text { з поліпшеними } \\
\text { аеродинаміч- } \\
\text { ними } \\
\text { характеристи- } \\
\text { ками } \\
\end{array}$ & & & 50 & 50 & $\begin{array}{c}56 \\
\text { снарядом V-LAP }\end{array}$ & & \\
\hline $\begin{array}{c}\text { Керованим } \\
\text { снарядом } \\
\text { “Краснополь”, км }\end{array}$ & & & & & & & 20 \\
\hline Скорострільність & 3 постр./Хв & 4 постр./хв & $\begin{array}{c}6 \\
\text { постр./хв }\end{array}$ & $\begin{array}{c}6 \\
\text { постр./хв }\end{array}$ & $\begin{array}{c}3 \text { постріли за } \\
\text { 9,2 сек. } \\
8 \text { пострілів- за } \\
\text { 51,4 сек. }\end{array}$ & $\begin{array}{c}8 \\
\text { постр./хв }\end{array}$ & $\begin{array}{c}10 \\
\text { постр./хв }\end{array}$ \\
\hline
\end{tabular}

\section{Висновки}

На основі порівняльного аналізу самохідних артилерійських систем провідних країн світу, виходячи з наявних тактикотехнічних характеристик, можемо зробити наступні висновки з визначенням напрямів, за якими необхідно проводити розвиток вітчизняних самохідних артилерійських систем.

Доцільно звернути увагу на наступне:

1) Перехід на 155 мм калібр гармати дає можливість підвищити ефективність осколкової дії снаряда до 10\%;

- при збільшенні довжини ствола до 52 калібрів, як наслідок, з сучасними метальним зарядом та відповідною геометрією снаряда зростає дальність стрільби;

- канал ствола повинен бути хромований для збільшення терміну експлуатації;

- оснащення гармати щілинним дульним гальмом нового зразка, який зменшить інтенсивність спалаху при покиданні снарядом ствола гармати та збільшить початкову швидкість снаряда;

2) Впровадження автоматизації процесів управління вогнем, топогеодезичної прив'язки та наведення автоматичної системи управління вогнем, системи навігації та наведення вимагає:

- оснащення САУ бортовим балістичним обчислювачем з інтегрованим розрахунком балістики з підтримкою режиму MRSI, при якому ціль уражається одночасно декількома снарядами, випущеними з однієї гармати;

- обладнання засобами закритого цифрового зв'язку з автоматичною зміною частоти;

- обладнання бортовою радіолокаційною станцією вимірювання початкової швидкості снаряда на кожну гармату для розрахунку поправок при стрільбі;

- оснащення САУ системою діагностики обладнання для своєчасного виявлення несправностей як базового шасі так й артилерійської частини.

3) Автоматизація процесу заряджання вимагає:

- оснащення САУ автоматичним механізмом подачі снарядів та зарядів;

$$
\text { - оснащення САУ бортовою }
$$
автоматизованою системою управління вогнем;

- оснащення САУ автоматичною установкою багатофункціонального підривника для використання керованих снарядів типу Excalibur або їм подібним.

4) Базове шасі повинно оснащуватися:

- вбудованою системою самодіагностики і електронною системою управління; 
- шасі високої прохідності;

- бронею, яка має захист від куль калібру до 12,7 мм та осколків снарядів, мін;

- системою клімат-контролю (для зимових та літніх умов);

- системою виявлення лазерного опромінення (підсвітки).

\title{
Список використаних джерел
}

1. Аналіз ведення антитерористичної операції у 2014 р. [Електронний ресурс]. - URL: http://www.mil.gov.ua/content/other/anliz_rf .pdf.

2. Вакал А.А., Бойко Г.О.Тенденції розвитку самохідних артилерійських систем провідних у військовому відношенні країн світу. Науково-технічний журнал "Озброєння та військова техніка" ЦНдІ ОВТ ЗСУ. 2014.

3. Бондаренко С., Семів Г., Бородавченко В., Федор Б., Звонко А. Проблеми балістичної підготовки і можливі шляхи вирішення. [Електронний ресурc]. - URL: https://www.u krmilitary.com/2021/05/arta.html.

4. Русаков В. Самоходная гаубица М109 история создания и этапы развития. Зарубежное военное обозрение. 2014. №2. C. 41-49.

5. Французская 155-мм САУ CAESAR".
[Електронний ресурс]. - URL: https://topwar.ru/72011-francuzskaya-155mm-sau-caesar.html.

6. Інерціальна система наведення та навігації Safran Electronics \& Defense. [Електронний pecypc]. - URL: https://www.safranelectronics-defense.com/land-defense/ artillery/navigation-pointing-artillery.

7. Панцергаубица третьего тысячелетия [Електронний ресурс]. - URL: https://warspot.ru/11619-pantsergaubitsatretiego-tysyacheletiya

8. Самоходная гаубица FH77BW L52 Archer (Швеция). [Електронний ресурс]. - URL: https://topwar.ru/33997-samohodnayagaubica-fh77bw-l52-archer-shveciya.html.

9. САУ Мста-С 2С19 - 152-мм самоходная гаубица. [Електронний ресурс]. - URL: https://wartools.ru/sau-russia/sau-msta-s$2 s 19 /$.

\section{Направления развития отечественных самоходных артиллерийских систем на основе анализа образцов артиллерийского вооружения ведущих стран мира}

\footnotetext{
Андрей Кислицин * 1 А; Николай Дорофеев ${ }^{2}$ в

* Corresponding author: ${ }^{1}$ Научный сотрудник научно-исследовательского отдела, e-mail: kislitsyn.andrey14@gmail.com, ORCID: 0000-0001-9838-7896 ${ }^{2}$ Научный сотрудник научно-исследовательского отдела, e-mail: dorofeev83@meta.ua, ORCID: 0000-0001-8607-2483

А Научно-исследовательский центр ракетных войск и артиллерии, г. Сумы, Украина

в Центральный научно-исследовательский институт вооружения и военной техники ВСУ, г. Киев, Украина
}

\begin{abstract}
Аннотация
Збройна агресія Російської Федерації на сході України внесла суттєві корективи в вітчизняний розвиток озброєння та військової техніки як у нашій країни так і за кордоном. Розвиток артилерійського озброєння, як основного виду вогневого ураження противника за досвідом антитерористичної операції (операції Об'єднаних Сил), є пріоритетним, оскільки чималий відсоток завдань з вогневого ураження противника припадає саме на артилерію. В даній статті розглянуто питання щодо формування напрямків розвитку вітчизняних самохідних артилерійських систем на основі аналізу зразків артилерійського озброєння провідних у військовому відношенні країн світу. Слід зазначити, що широке впровадження сучасних технологій та науково-технічних рішень для підвищення ефективності застосування зразка озброєння та військової техніки є одним з головних напрямів розвитку артилерійського озброєння для часткового вирішення проблем, пов'язаних з розвитком форм збройної боротьби.
\end{abstract}

Ключевые слова: САУ, інерційні системи навігації та наведення, НАТО, аналіз, снаряд. 


\title{
Directions for the development of domestic self-propelled artillery systems based on the analysis of samples of artillery weapons from the leading countries of the world
}

\author{
Andrey Kislitsyn * 1 A; Nikolay Dorofeev ${ }^{2 \mathrm{~B}}$ \\ * Corresponding author: ${ }^{1}$ Researcher of the research department, e-mail: kislitsyn.andrey14@gmail.com, ORCID: 0000-0001-9838-7896 \\ ${ }^{2}$ Researcher of the research department, e-mail: dorofeev83@meta.ua, ORCID: 0000-0001-8607-2483 \\ A Research Center for Missile Forces and Artillery, Sumy, Ukraine \\ ${ }^{B}$ Central Research Institute of weapons and military equipment of the Armed Forces of Ukraine, Kyiv, Ukraine
}

\begin{abstract}
The armed aggression of the Russian Federation in the east of Ukraine has made significant adjustments to the domestic development of weapons and military equipment both in our country and abroad. The development of artillery weapons as the main type of effective engagement of the enemy according to the experience of the anti-terrorist operation (operation of the Joint Forces) is a priority, since a considerable percentage of the tasks of engaging the enemy with fire falls on artillery. This article discusses the formation of directions for the development of domestic self-propelled artillery systems based on the analysis of samples of artillery weapons from the militarily leading countries of the world. It should be noted that the widespread introduction of modern technologies and scientific and technical solutions to increase the effectiveness of the use of a model of weapons and military equipment is one of the main directions of the development of artillery weapons for a partial solution of problems associated with the development of forms of warfare.
\end{abstract}

Keywords: SPG, inertial navigation and guidance systems, NATO, analysis, shell.

\section{References}

1. Analiz vedennya antyterorystychnoyi operatsiyi u 2014 r. [Elektronnyy resurs]. - Available from: http://www.mil.gov.ua/content/other/anliz_rf .pdf.

2. Vakal, A.A. Boyko, H.O. (2014). Tendentsiyi rozvytku samokhidnykh artyleriys'kykh system providnykh u viys'kovomu vidnoshenni krayin svitu. Naukovo-tekhnichnyy zhurnal "Ozbroyennya ta viys'kova tekhnika" TSNDI OVT ZSU. 2014.

3. Bondarenko, S. Semiv, H. Borodavchenko, V. Fedor, B. Zvonko A. Problemy balistychnoyi pidhotovky i mozhlyvi shlyakhy vyrishennya. [Elektronnyy resurs]. - Available from: https://www.ukrmilitary.com/2021/05/arta.ht $\mathrm{ml}$.

4. Rusakov V. (2014). Samokhodnaya haubytsa M109 ystoryya sozdanyya y étapy razvytyya. Zarubezhnoe voennoe obozrenye. 2014. №2. S. 41-49.
5. Frantsuzskaya
$155-\mathrm{mm}$
SAU
CAESAR.

[Elektronnyy resurs]. - Available from: https://topwar.ru/72011-francuzskaya-155mm-sau-caesar.html.

6. Inertsial'na systema navedennya ta navihatsiyi. Safran Electronics \& Defense. [Elektronnyy resurs]. - Available from: https://www.safranelectronics-defense.com/land-defense/ artillery/navigation-pointing-artillery.

7. Pantserhaubytsa tret'eho tysyacheletyya [Elektronnyy resurs]. - Available from: https://warspot.ru/11619-pantsergaubitsatretiego-tysyacheletiya.

8. Samokhodnaya haubytsa FH77BW L52 Archer (Shvetsyya). [Elektronnyy resurs]. - Available from: https://topwar.ru/33997-samohodnayagaubica-fh77bw-l52-archer-shveciya.html.

9. SAU Msta-S 2S19 - 152-mm samokhodnaya haubytsa. [Elektronnyy resurs]. - Available from: https://wartools.ru/sau-russia/saumsta-s-2s19/. 